\title{
Prognosis of non traumatic coma: The role of some socio-economic factors on its outcome in Ibadan, Nigeria
}

\section{O. R Obiako, A. Ogunniyi ${ }^{1}$, E. Anyebe ${ }^{2}$}

Department of Medicine, Neurology Unit, Ahmadu Bello University Teaching Hospital, Nigeria, Zaria, 'Department of Medicine, Neurology Unit, University College Hospital, Ibadan, 'Department of Nurse Education, Ahmadu Bello University Teaching Hospital, Zaria, Nigeria

Comespondenceto: Dr O.R Obiako, Neurology unit, Department of Medicine, Ahmadu Bello University Teaching Hospital, Zaria, Nigeria. E-mail: reginaldobiako@ yahoo.com

\begin{abstract}
Background: Coma occurring in the course of an illness, irrespective of cause, traditionally implies a poor prognosis and many factors may determine its outcome. These factors must be identified and possibly stratified in their order of importance. This research seeks to identify these factors and how they influenced the outcome of non-traumatic coma in our environment.

Methods: Two hundred consecutive patients, aged 18-79 years who met the inclusion criteria, the Glasgow coma scale (GCS) score of $\varangle$, history and physical findings suggestive of medical illness, no head trauma or sedation, were recruited into the study from August 2004 to March 2005 at the University College Hospital (UCH), Ibadan, after obtaining institutional ethical clearance and consent from patients' guardians. Detailed history of illness including the bio-data and time to present to the hospital and treatments given were noted. Thereafter, the clinical course of the patients was monitored daily for a maximum of 28 days during which the support of the family and/ or the hospital social welfare was evaluated.

Results: During the 8-month period of the study, $76 \%$ (152) of the patients died while $24 \%$ (48) survived. The following factors were associated with high mortality rate: inability to confirm diagnosis (100\%), poor family support (97.1\%), delay in making a diagnosis within $24 \mathrm{~h}(85.4 \%)$, poor family understanding of disease $(84.1 \%)$, need for intensive care admission and management (83.3\%), poor hospital social welfare support (82.4\%), presentation to UCH after $6 \mathrm{~h}$ of coma (76.7\%), and referral from private health facilities (75.7\%). Others include substance abuse (100\%) and seropositivity to HIV (96\%) and hepatitis B surface antigen (92\%) antibodies, among others.

Conclusion: This study has demonstrated that socio-economic factors such as gender, occupation, risky lifestyle behaviors, late presentation or referral to hospital, late diagnosis and treatment, and poor family support contributed to poor outcome of nontraumatic coma. It is hoped that improvement, modification, or correction of these factors may improve coma outcome.
\end{abstract}

Keywords: Coma, mortality, Nigeria, nontraumatic coma, socio-economic factors

\section{Résumé}

Arrière-plan: Coma survenant au cours d'une maladie, indépendamment de la cause, traditionnellement implique un pronostic et de nombreux facteurs peuvent déterminer ses résultat. Ces facteurs doivent être identifiés et éventuellement stratifiées dans leur ordre d'importance. Cette recherche vise à identifier ces facteurs et comment ils influencé l'issue du coma non traumatique dans notre environnement.

Méthodes: deux cents consécutives patients, âgés de 18-79 ans qui satisfait aux critères inclusion: [ le Glasgow score de scale(GCS) de coma de $<8$, histoire et suggestives de physiques conclusions maladie médicale, aucune tête traumatisme ou sédation] ont été recrutés dans le étude d'août 2004 à mars 2005 à l'hôpital Université du College (hommes), Ibadan après obtention de dédouanement éthique institutionnel et consentement de tuteurs ' patients. Détaillées histoire de la maladie, y compris la Bio-données et de temps de présenter à l'hôpital et les traitements 
donnés ont été noté.Par la suite, le cours clinique des patients a surveillé quotidiennement pour un maximum de 28 jours au cours de laquelle le soutien de la famille et / ou l'hôpital de bien-être social a été évaluée.

Résultats: Durant la période de 8 mois l'étude, $76 \%$ (152) des patients sont morts pendant $24 \%(48)$ ont survécu. Les facteurs suivants ont été associé à taux élevé de mortalité: impossibilité de confirmer le diagnostic (100\%), soutien aux familles pauvre $(97,1 \%)$, délai en faire un diagnostic dans les 24 heures (85.4\%), mauvaise compréhension familiale de maladie $(84,1 \%)$, besoin de soins intensifs admission et de gestion (83.3\%), support de bien-être social hôpital pauvres (82.4\%), Présentation aux hommes après 6 heures de coma (76.7 \%) et d'orientation du privé établissements de santé (75.7\%). D'autres incluent des abus de substances (100\%), séropositivité au VIH (96\%) et les anticorps de surface antigène ( $92 \%$ ) de l'hépatite $B$, entre autres.

Conclusion: cette étude a démontré que facteurs socio-economic tels que le sexe, profession, comportements lifestyle risquée, Présentation tardive ou de renvoi à l'hôpital, de diagnostic tardif et de traitement, et soutien aux familles pauvre ont contribué au résultat pauvre de coma nontraumatic .il est espéré que i mprovement, de modification ou correction de ces facteurs peut-être améliorer coma issue

Mots cles: coma, mortalité, coma nontraumatic, facteurs socio-économiques, Nigeria

DOI: $10.4103 / 1596-3519.56240 \quad$ PMID: 19805943

\section{Introduction}

For hundreds of years, scientists have tried to make sense of why diseases occur at certain times, in certain places, and in certain people. Some earlier studies had suggested that supernatural events caused sickness, whereas others such as hippocrates related it to lifestyle and environmental conditions. The modern view of disease cauzation relies on multifactorial explanations. It is now recognized and accepted that particular agents of disease such as micro-organisms, dietary substances, and the likes interact with many social factors, such as poverty, ignorance, and susceptible lifestyles such as alcoholism, smoking, homosexuality, and lack of exercise, to cause disease. ${ }^{[1]}$

The link between ill-health and socio-economic status was highlighted by reports of the National Cholesterol Education Program Expert Pane ${ }^{[2]}$ and Greenwald et al, ${ }^{[3]}$ which established the significance of social inequalities and poverty in the genesis of disease. It is quite simple to identify the relationship between the exposure to risk and an adverse outcome especially in infectious diseases. ${ }^{[1,4]}$ However, in chronic diseases such as cancer, metabolic, and heart diseases, it is less clear and even more ambiguous and complex when such illnesses result to coma. This is because, irrespective of cause, coma rarely lasts more than 2-4 weeks without an outcome, which can be either of the following: recovery with no disability, recovery with various degrees of disability, vegetative state, or death. ${ }^{[5]}$ In these cases, it is difficult for clinicians to develop estimates of risks based on their limited experience. An individual clinician may perhaps see neither the resulting outcome following an exposure nor enough patients to determine which of many possible risk factors are the most important. ${ }^{[6]}$
Through the use of case-control and cohort studies, (as in the present study), risk and prognostic factors can be determined, which will allow screening programs and health promotion strategies aimed at changing risk behaviors to be established. ${ }^{[4]}$

According to the literature, socio-economic factors may contribute more to the outcome of non-traumatic coma than has previously been recognized. ${ }^{[7]}$ These factors include socio-economic variables in the individual patients, their families, and the hospitals or health institutions. ${ }^{[8]}$ The age, sex, and occupation of the patients are important social determinants of the behavioral pattern. The family as a support system and decision makers for the patients' health-seeking pathways or behavior appears to be relevant, just as the hospital structure and mode of intervention, measured in terms of time and quality of medical intervention and social support for the indigent patient. ${ }^{[8]}$

The early recognition of patients who may require aggressive therapeutic measures is important, since animal and human studies have proved that early intervention results in better outcome. ${ }^{[9]}$ With good and quick medical intervention, many patients now survive illnesses which would previously have proved fatal, especially those associated with acute failure in one bodily system or another. ${ }^{[10]}$ Coma occurring in the course of an illness, irrespective of cause, implies a poor outcome, and physicians and families of comatose patients often have to make difficult decisions as they consider whether life extending care will achieve desirable outcomes. ${ }^{[11]}$ Health care planners also need to know the outcome of intensive care and other life-support services offered to comatose patients, for the purposes of planning and resource allocation. ${ }^{[12]}$ These decisions and knowledge will be easier if information is 
available on what happened to previous cases of same kind. This research therefore seeks to identify these and other social factors affecting the outcome of non-traumatic coma in our environment.

\section{Materials and Methods}

This was a prospective longitudinal study involving 200 adults ( $\geq 18$ years) who presented to University College Hospital (UCH) Ibadan with strictly defined coma [Glasgow coma scale (GCS) score of $\leq 8$ ], excluding patients with head injury or other causes of surgical coma. This was done with the permission of the Institutional Research Committee of UCH and the consent of the patients' relatives. The patients were first evaluated in the accident and emergency (A and E) unit on presentation before transfer to the intensive care unit or medical ward as the condition of the patients demanded. The relevant history of the illness was taken, especially the sociodemographic characteristics, interval between the onset of loss of consciousness and presentation to $\mathrm{UCH}$, mode of presentation (referred or brought direct from home). Thereafter, the clinical course of each patient was monitored daily for a maximum of 28 days ${ }^{[5]}$ during which the following were noted: the quality of clinical services rendered to the patients (onset of resuscitation, interval between presentation to $\mathrm{A}$ and $\mathrm{E}$ and diagnosis and/or treatment, availability of relevant diagnostic/investigative tools, nursing care, skin/oral/perinea care, catheter management, development of complications. The ability of the family to pay for relevant investigations and drugs was used to assess their level of support for the patient using an aggregate score of $100 \%$ from five parameters: payment for laboratory investigations, procurement of drugs, payment of physiotherapy fees, payment of other hospital charges, and availability of at least one relation on demand. The same parameters were used to assess the level of hospital social welfare support for indigent patients (in this case, availability of at least one relation on demand was replaced by patient seen by one social worker at least two times per week of stay). A self-administered close ended questionnaire was used to assess both the family and guardians' understanding of the patient's illness. This was scored using the University of Ibadan examination marking scheme. On the 28th day of hospital stay, the outcome of patients' illness was defined in terms of death or survival ${ }^{[5]}$ and data were then subjected to frequency distribution, chi square, and multiple response analysis using the Statistical Package for Social Sciences (SPSS) version 10.0.

\section{Results}

One hundred and fifty-two of the 200 patients studied died giving an overall mortality of $76 \%$. There was an overall male predominance of $66 \%$ (132) over the females' 34\% (68). However, the difference between the respective mortality rates of $78.8 \%$ and $70.6 \%$ was not of statistical significance $\left(\chi^{2}=1.65, P>0.05\right)$. The mean age of all the patients was $50+18$ years, the males being slightly but insignificantly younger $(49.5+16.1$ years) than the females $(50.9+20.9$ years). ( $t=-0.514, P>0.05)$. Mortality was highest in the 40-59 age group with $80.5 \%$ followed up, respectively, by the $>60$ years old $(76.5 \%)$ and $<39$ years old $(69.1 \%)$. Again, there was no statistically significant difference in these mortality rates.

Occupational distribution showed that the selfemployed (made up of small scale businessmen, traders, artisans, taxi drivers, commercial motorcyclists, farmers, clergymen) constituted $52.5 \%$ of the study population, followed by the unemployed (students, housewives, the retired/or disengaged from service/job) who constituted $28.5 \%$ and lastly the public/civil servants who made up the remaining $19 \%$. The mortality rates, however, showed that the self-employed had the highest rate of $81 \%$ followed by the public/civil servants with $79 \%$ and the unemployed with the lowest rate of $65 \%\left(\chi^{2}=5.45, P=0.66\right)$.

Although Christians (62\%) were more than Moslems (38\%) among the study population, religious affiliation did not have any significant impact on outcome $\left(\chi^{2}=0.07, P=1.2\right)$. The impact of ethnicity could not be assessed, as $95 \%$ of these patients were Yoruba, while the other $4.5 \%$ were from other Nigerian tribes and $0.5 \%$ Senegalese.

Generally, mortality was higher $(76.7 \%)$ in the $45 \%$ (90) patients who presented after $6 \mathrm{~h}$ than the 55\% (110) who were brought within $6 \mathrm{~h}$ $(63.2 \%)$, although the difference was not statistically significant $\left(\chi^{2}=2.45, P=0.12\right) .32 .5 \%$ (65) of the patients who presented after $6 \mathrm{~h}$ were referred from primary and secondary health facilities with a mortality rate of $89.6 \%$, while the other $12.5 \%$ (25) brought in directly from their homes had a mortality rate of $68.7 \%\left(\chi^{2}=1.00, P=0.00\right)$.

Although $99 \%$ of the patients had resuscitative measures started $<1 \mathrm{~h}$ on presentation to the accident and emergency (A and E) unit, this did not translate into lower mortality as $75.5 \%$ of them died $\left(\chi^{2}=0.749, P=0.382\right)$ [Table 1]. Mortality was worst in patients admitted into the intensive care unit (ICU) (83.3\%), followed by those in 
the (A and E) unit with $80 \%$ and lastly $75.1 \%$ for patients admitted into the medical wards, although the differences were not statistically significant $\left(\chi^{2}=0.464, P=0.793\right)$. Mortality was higher $(85.4 \%)$ when diagnosis was delayed beyond $24 \mathrm{~h}$ than when it was confirmed before $24 \mathrm{~h}(73.6 \%)$, although the difference was also not statistically significant as more than two-third (79.5\%) of the patients had their medical condition diagnosed within $24 \mathrm{~h}\left(\chi^{2}\right.$ Page $\mid 118$ $=2.48, \mathrm{P}=0.115$ ) [Table 2].

All 17.5\% (35) patients who had no investigations died (100\% mortality), while the remaining $82.5 \%$ (165) who had some or all relevant investigations had a mortality rate of $67.3 \%$. This difference was statistically significant $\left(\chi^{2}=14.04, P=0.000\right)$. This is shown in Figure 1.

Family support had a strong influence on outcome $\left(\chi^{2}=27.07, \mathrm{P}=0.000\right)$. The mortality rate of $56.8 \%$ in patients who had excellent family support was lower than $86.1 \%$ and $97.1 \%$, respectively, for those who had good and poor family support [Table 3].

Similar significant results on outcome were also seen with family knowledge of the cause of coma, $\chi^{2}=7.84, P=0.02$ [Table 4], as mortality was highest $(84.1 \%)$ in patients whose family members had the least knowledge and lowest $(64.8 \%)$ in those whose family members had excellent knowledge. The effect of hospital social welfare service support on coma outcome in Table 5 showed that the highest mortality rate of $82.4 \%$ was seen in patients who were offered $<50 \%$ support, followed by $75 \%$ in the many others who for various reasons could not have access to the hospital support system, although the mortality rate in the very few $(2 \%)$ who were offered excellent support was also high $\left(\chi^{2}=0.591, \mathrm{P}=0.74\right)$.

The mortality rate was found to be higher in patients with high-risk lifestyle behaviors/disease-promoting factors than those without these attributes. For instance, substance abuse (marijuana, tobacco, cigarette smoking) was associated with a mortality of $100 \%$, HIV with $95.2 \%$, hepatitis B surface antigenemia (92.3\%), hyperglycemia (86\%), hypertension $(83.1 \%)$, alcohol abuse $(82.4 \%)$, and obesity with $64.3 \%$. This is shown in Table 6 .

\section{Discussion}

Age has been identified in many studies as a strong

Table 1: Effect of delay before onset of resuscitation on outcome

\begin{tabular}{|c|c|c|c|c|c|c|}
\hline $\begin{array}{l}\text { Hours before } \\
\text { resuscitation }\end{array}$ & Survived & Died & Total & Mortality rate & $\chi^{2}$ & $P$-value \\
\hline$\leq 1 \mathrm{~h}$ & $47(23.5)$ & $151(75.5)$ & 198(99) & 75.5 & 0.749 & 0.382 \\
\hline$\geq 1 \mathrm{~h}$ & $1(0.5)$ & $1(0.5)$ & $2(1)$ & 24.5 & & \\
\hline Total & $48(24)$ & $152(76)$ & $200(100)$ & & & \\
\hline
\end{tabular}

\begin{tabular}{|c|c|c|c|c|c|c|}
\hline $\begin{array}{l}\text { Hours before } \\
\text { diagnosis }\end{array}$ & Survived (\%) & Died (\%) & Total & Mortality rate & $\chi^{2}$ & $P$-value \\
\hline$\leq 24 \mathrm{~h}$ & $42(21)$ & $117(58.5)$ & $159(79.5)$ & 73.6 & 2.48 & 0.115 \\
\hline$>24 \mathrm{~h}$ & $6(3)$ & $35(17.5)$ & $41(20.5)$ & 85.4 & & \\
\hline Total & $48(24)$ & $152(76)$ & $200(100)$ & & & \\
\hline
\end{tabular}

\begin{tabular}{lcccccc}
\hline \multicolumn{6}{l}{ Table 3: Influence of family support on coma outcome } \\
\hline Family support & Survived (\%) & Died (\%) & Total(\%) & Mortality rate & $\chi^{2}$ & P-value \\
\hline Excellent $80-100 \%)$ & $36(18)$ & $51(25.5)$ & $87(43.5)$ & 56.8 & 27.07 & 0.000 \\
Very good/good (5079\%) & $11(5.5)$ & $68(34)$ & $79(39.5)$ & 86.1 & & \\
Poor/ very poor (<50\%) & $1(0.5)$ & $33(16.5)$ & $34(17)$ & 97.1 & & \\
Total & $48(24)$ & $152(76)$ & $200(100)$ & & & \\
\hline
\end{tabular}

\begin{tabular}{|c|c|c|c|c|c|c|}
\hline $\begin{array}{l}\text { Family knowledge of } \\
\text { cause of coma }\end{array}$ & Survived (\%) & Died (\%) & Total & Mortality rate & $\chi^{2}$ & $P$-value \\
\hline Excellent $(80-100 \%)$ & $25(12.5)$ & $46(23)$ & $71(35.5)$ & 64.8 & 7.84 & 0.02 \\
\hline Very good/good (50-79\%) & $13(6.5)$ & $53(26.5)$ & $66(33.0)$ & 80.3 & & \\
\hline Poor/ very poor $(<50 \%)$ & $10(5)$ & $53(26.5)$ & $63(31.5)$ & 84.1 & & \\
\hline \multirow[t]{2}{*}{ Total } & $48(24)$ & $152(76)$ & $200(100)$ & & & \\
\hline & & $152(76)$ & & & & \\
\hline
\end{tabular}




\begin{tabular}{|c|c|c|c|c|c|c|}
\hline $\begin{array}{l}\text { UCH social welfare } \\
\text { support }\end{array}$ & Survived (\%) & Died (\%) & Total (\%) & Mortality rate & $\chi^{2}$ & $P$-value \\
\hline Excellent (80-100\%) & $1(0.5)$ & $3(1.5)$ & $4(2)$ & 75 & 0.591 & 0.744 \\
\hline Very good/good (50-79\%) & $5(2.5)$ & $14(7)$ & $23(11.5)$ & 61 & & \\
\hline Poor/ very poor $(<50 \%)$ & $6(3)$ & 28(14) & $34(17)$ & 82.4 & & \\
\hline Not sought for & $36(18)$ & $107(53.5)$ & $143(71.5)$ & 74.8 & & \\
\hline Total & $48(24)$ & $152(76)$ & $200(100)$ & & & \\
\hline
\end{tabular}

\begin{tabular}{lcccccccc}
\hline \multicolumn{2}{l}{ Table 6: Effect of some risk factors on outcome of coma } \\
\hline Characteristics & $\begin{array}{c}\text { Hypertension } \\
(\%)\end{array}$ & $\begin{array}{c}\text { Diabetes } \\
\text { mellitus } \\
(\%)\end{array}$ & $\begin{array}{c}\text { HIV } \\
(\%)\end{array}$ & $\begin{array}{c}\text { Alcohol } \\
\text { use (\%) }\end{array}$ & $\begin{array}{c}\text { Old age } \\
(\%)\end{array}$ & $\begin{array}{c}\text { Obesity } \\
(\%)\end{array}$ & $\begin{array}{c}\text { Hepatitis } \\
\text { B surface } \\
\text { antigenemia (\%) }\end{array}$ & $\begin{array}{c}\text { Substance } \\
\text { abuse (\%) }\end{array}$ \\
\hline Alive & $13(6.5)$ & $4(2)$ & $2(1)$ & $3(1.5)$ & $3(1.5)$ & $5(2.5)$ & $1(0.5)$ & - \\
Dead & $64(32)$ & $24(12)$ & $21(10.5)$ & $14(7)$ & $11(5.5)$ & $9(4.5)$ & $12(6)$ & $8(4)$ \\
Total & $77(38.5)$ & $28(14)$ & $23(11.5)$ & $17(8.5)$ & $14(7)$ & $14(7)$ & $13(6.5)$ & $8(4)$ \\
Good outcome \% & 16.9 & 14 & 4.8 & 17.6 & 21.4 & 35.7 & 7.7 & - \\
Poor outcome \% & 83.1 & 86.0 & 95.2 & 82.4 & 78.6 & 64.3 & 92.3 & 100 \\
\hline
\end{tabular}

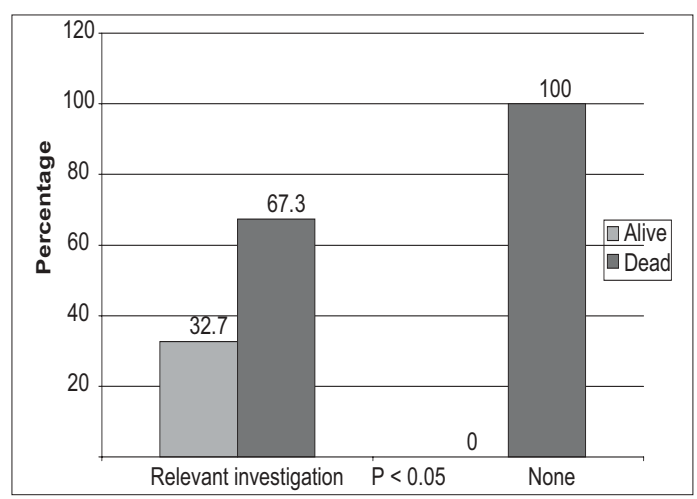

Figure 1: Distribution of outcome according to ability to do relevant investigations

prognostic factor in coma of any etiology. In the Study to Understand Prognoses and Preferences for Outcomes and Risks of Treatments (SUPPORT), age of 70 years or older was one of five clinical independent variables associated with 2-month mortality in non-traumatic coma. ${ }^{[13]}$ A study involving 562 patients identified infancy and age above 50 years as strong predictors of poor outcome in acute meningococcemia. ${ }^{[14]}$ Other studies on acute hepatitis, ${ }^{[15]}$ cerebrovascular ${ }^{[16]}$ and cardiovascular ${ }^{[17]}$ diseases corroborated the effect of extremes of age on coma outcome. In this study, the age group 4059 years had the highest mortality rate of $80.5 \%$, followed closely by the age group $\geq 60$ years with $76.5 \%$, and lastly by the $\leq 39$ years age group with $69.1 \%$. Although this result was contrary to expected trends, the difference in the mortality rates was not statistically significant and may have been a reflection of the proportional size of the age groups that were $38.5 \%, 34.0 \%$ and $27.5 \%$ respectively.

Many studies have reported a higher male to female ratio in the risk factors and causes of medical coma at ages of 65 years and below except subarachnoid hemorrhage with a female preponderance. ${ }^{[18,19]}$ The result of this study has confirmed this trend. Many reasons have been adducted to explain this trend, especially in Africa. ${ }^{[16,18]}$ One of them is that males being the breadwinners have the resources to treat themselves, while the females must depend on the goodwill of the males to be brought to the hospital whenever they fall sick. Also, there is the tendency to care for the male child more than the female. Lastly, it is believed that males have more risky or disease promoting lifestyles than females and so are more likely to fall sick and present to hospital.

Socioeconomic status has been shown to contribute to geographical variations in the etiology and prognosis of coma. ${ }^{[8,20,21]}$ In many developing countries, infections are the most common cause of medical coma, because the distribution of infectious agents parallels the poor socioeconomic conditions in these countries. ${ }^{[20]}$ Apart from infections, factors such as ignorance and low literacy rate, non-availability of suitable drugs and medicines, self-medications and patronage of traditional medicine practitioners, overcrowding, delayed presentation to hospital and lack of money, or facilities for proper investigations and treatment contribute to high mortality in these countries. ${ }^{[20-24]}$ Delayed presentation to hospital was a major factor in this study. About $45 \%$ of the patients were brought to hospital more than $6 \mathrm{~h}$ after onset of coma, and this group had statistically significantly higher mortality. Many of these patients (32\%) were referred from private hospitals and other primary and secondary health facilities where they were first seen. Many of these patients presented to UCH with co-morbid illnesses and complications, hence the higher mortality. This also agrees with the observations of other workers, particularly with respect to stroke ${ }^{[18]}$ and hypoglycemia ${ }^{[22,23]}$ especially in Africa. In some countries where many hospitals 
lack equipment for electroencephalogram (EEG) and other neurophysiologic studies, mortality from non-convulsive status epilepticus might be high since many cases would be unrecognized. In a Lusaka hospital, only 3 out of 33 patients whose cause of coma could not be found, due to the lack of proper investigative tools and intensive care facilities, survived. ${ }^{[23]}$ In this study, although mortality rate was highest in patients admitted into the intensive care unit, it was not significantly different from the rates observed in patients either in the accident and emergency unit or on the medical wards. The reasons for this result may not be farfetched. All illnesses leading to coma portend a poor prognosis. High hospital charges, limited bed space, and no facilities for intensive care ensure exclusion of many who need these services and delayed resuscitation for the few patients who are privileged to access the care.

In this study, patients who had above $50 \%$ family support and were able to pay for some relevant investigations had a better outcome than those who had poor or less than $50 \%$ family support or failed to pay for investigations. This report is in consonance with those of Cullen et al. ${ }^{[9]}$ and Jorgensen et al. ${ }^{[25]}$

These studies suggested that less aggressive care for the elderly by family members and health care providers was responsible for poor functional outcome, while the presence of a spouse was a strong predictor of a good functional outcome in young patients with the most severe strokes. ${ }^{[25]}$

High-risk lifestyle behaviors ${ }^{[2]}$ such as cigarette smoking, alcohol and/or substance abuse, and physical inactivity when associated with diabetes mellitus, hyperlipidemia, homocysteinemia, hypertension, atherogenic dyslipidemia, visceral obesity, impaired fibrinolysis, and left ventricular dysfunction, individually and collectively, contribute to poor outcome in renal, metabolic, cerebrovascular, and/or cardiovascular events. It is, therefore, hoped that with the identification of many prognostic factors by this study supported by those of earlier studies, health care providers would be able to improve the outcome of coma. ${ }^{[26]}$

\section{Conclusion}

This study has demonstrated that socio-economic factors such as gender, occupation, high risk lifestyle behaviors, late presentation or referral to hospital, late diagnosis and treatment, and poor family support contributed to poor outcome of non-traumatic coma. It is hoped that improvement, modification, or correction of these factors may improve coma outcome. For example, measures should be taken to improve the referral system from private health facilities, which are usually the first emergency port of call for many families. This could be done through continuing medical education and public health enlightenment campaigns. Hospital social welfare services should be strengthened to cater for the needs of indigent patients. Diagnosis of diseases may be faster if diagnostic tools that are accessible to the clinicians and affordable by the patients are made available in public hospitals.

\section{References}

1. Snider GI. Tuberculosis, then and now: A personal perspective on the last 50 years. Ann Intern Med 1997;126:237.

2. Report of the National Cholesterol Education Program Expert Panel on detection, evaluation and treatment of high blood cholesterol in adults. Arch Intern Med 1988;148:36-69.

3. Greenwald P, Sherwood K, McDonald SS. Fat, caloric intake, and obesity: Lifestyle risk factors for breast cancer. J Am Diet Assoc 1997;97:S24-30.

4. Lemp GF, Hirozawa AM, Givertz D, Nieri GN, Anderson $L$, Lindegren $M L$, et al. Seroprevalence of HIV and risk behaviours among young homosexuals and bisexual men. JAMA 1994;272:449-54.

5. Bates D, Caronna JJ, Cartlidge NE, Knill-Jones RP, Levy $D E$, Shaw DA, etal. A prospective study of non-traumatic coma: Methods and results in 310 patients. Ann Neurol 1997:2:211-20.

6. Gallagher EJ. Clinical utility of likelihood ratios. Ann Emerg Med 1998;31:391.

7. Bondi FS. Childhood coma in Ibadan: Relationship to socio-economic factors. Trop Geog Med 1991;43:288-92.

8. Cullen DJ, Ferrara LC, Briggs BA, Walker PF, Gilbert J. Survival, hospital charges and follow-up results in critically ill patients. N Engl J Med 1976;294:982-7.

9. Malik K, Hess C. Evaluating the comatose patient: Rapid neurologic assessment is key to appropriate management. Postgrad Med 2002;111:38-55.

10. CaronnaJJ, Simon RP.The comatose patient: A diagnostic approach and treatment. Int. Anesth Clin 1979;17:3.

11. Fletcher GP. Legal aspects of the decision not to prolong life. Moral problems in medicine. In: Gorovitzs, Jameton A, Macklin R, et al, editors. Eaglewood cliffs. NJ Prentice Hall; 1976. p. 261-6.

12. Lynn J, Harrel FJr. Prognoses of seriously ill hospitalized patients on the days before death: Implications for patient care public policy. New Horizons 1997;5:56-61 .

13. Murphy DJ, Cliff LE, editors. SUPPORT: Study to understand prognoses and preferences for outcomes and risks of treatments. J Clin Epidemiol 1990;43:15.

14. Lodder MC, Schildkamp RL. Prognostic indicators of the outcome of meningococcal disease: A study of 562 patients. J Med Microbiol 1996;45:16-20 .

15. Otegbayo JA. Complications contributing to mortality in acute hepatitis at the University College Hospital, Ibadan, Nigeria. Niger J Med 2001;10:127-9.

16. Dada TC, Johnson FA, Araba AB. Cerebrovascular accidents in Nigerians: A review of 205 cases. West Afr Med J 1969;18:95-108.

17. O' Keefe JH Jr, Miles JM, Harris WH, Moe RM, McCallister $\mathrm{BD}$. Improving the adverse cardiovascular prognosis of type 2 DM. Mayo Clin Proc 1999;74:171-80.

18. Osuntokun BO, Odeku EL, Adeloye RB. Cerebrovascular accidents in Nigerians: A study of 348 patients. West Afr 
Med J 1969;18:160-73.

19. Kolawole BA, Ajayi AA. Prognostic indices for intrahospital mortality in Nigerian diabetic NIDDM patients. Role of gender and hypertension. J Diabetes Compl 2000;14:84-9.

20. Pallangyo KJ, Yusufali AM, McLarty DG, Salim SS. Treatment of diabetic coma in a tropical environment. Trop Doctor 1984;14:72-5.

21. Osuntokun BO, Akinkugbe FM, Francis TI, Reddy S, Osuntokun O, Taylor GO. Diabetes mellitus in Nigerians: A study of 832 patients. West Afr Med J 1971:295-311.

22. Lester PT. Severe hypoglycemic reactions in Ethiopian diabetics. Ethiopian Med J 1982;20:33.

23. Sinclair GR, Watter DA, Bagshaw A. Non-traumatic coma in Zambia. Trop Doctor 1989;19:6-10.
24. Greenwood BM, Bradley K, Cleland PG, Haggie MH, Hassan-King M, Lewis LS, et al. An epidemic of meningococcal infection in Zaria; Northern Nigeria: I: General epidemiological features. Tran Roy Soc Med Hygiene 1979;73:557-63.

25. Jorgensen HS, Reith J, Nakayama H, Raaschou HO, Olsen TS. What determines good recovery in patients with the most severe stroke? The Copenhagen stroke study. Stroke 1999;30:2008-12.

26. Plum F, Levy D. Predicting prognosis in coma, can one improve medical decision? Am J Med 1978:65:224-6.

Page | 121

Source of Support: Nil, Conflict of Interest: None declared. 